\title{
LIFE SATISFACTION AMONG PEOPLE AGED 60 AND OVER, PARTICIPATING IN RESTRICTED SOCIAL NETWORKS IN POLAND: RELATED VARIABLES
}

\author{
Agnieszka Kozerska \\ Jan Długosz University in Częstochowa, Poland \\ E-mail: a.kozerska@ajd.czest.pl
}

\begin{abstract}
From the perspective of adult education, the engagement of older people in developing relationships with other people is related to their learning and creating their identities. The research conducted in the areas of various countries shows a relationship between a social participation of seniors and their wellbeing. Moreover, participation in rich social networks, composed of many people, coincides with a high quality of life. The article focuses on senior citizens functioning in restricted networks (less numerous social networks, consisting of several people).The study is to serve three purposes: firstly, to identify determinants of a subjective assessment of own life of senior citizens living in restricted networks; secondly, to analyse a relationship between seniors'subjective, general assessment of life and their opinion on what determines a successful and happy life; thirdly, to analyse the relationship between seniors' subjective, general assessment of life and the ways they handle problematic situations. The analysis has been conducted on the basis of the data collected in 2013, available to the general public on www.diagnoza.com. The data was collected within the Social Diagnosis (Diagnoza spoleczna) project. The objective of the Social Diagnosis is an investigation of the conditions and quality of life in Poland. It is based on panel research. A questionnaire has been used as a research tool. The article presents information regarding 5623 individuals, aged 60+functioning in restricted social networks in Poland. The Mann-Whitney U test and the two proportions test helped to analyse the differences between variable distributions. The results show that a poor social life of the elderly does not have to be linked with a feeling of loneliness. The group of individuals with a high level of general satisfaction is more satisfied with a relationship with the family (especially children) than the group with a low level of life satisfaction. The analysis confirms that good relationships with family and friends are an important predictor of life satisfaction of the elderly. Health is considered to be a condition of a successful life by seniors with a high level of life satisfaction, as well as relationships with close family members: with children and a spouse. This group of respondents shows more confidence in other people, by whom they feel loved and confided in. In difficult situations people with a high level of life satisfaction turn to others for help, but they also act themselves. Seniors with a low level of satisfaction differ from the previous group in these terms. These are people who do not feel confided in by others and they also hardly ever turn to others for help. In difficult situations they are more often passive. In conclusion, the author highlights the significance of informal learning occurring in families to enhance older people's quality of life. It is important, especially in case of poorly educated persons with low incomes who often function in small social networks.

Key words: informal learning in the family, life satisfaction of older adults, social participation of seniors.
\end{abstract}

\section{Introduction}

As people get older, they are more likely than others to experience social isolation and loneliness as a result of various factors, such as retirement, the death of a spouse or friends, the deterioration of health and financial condition resulting from ceasing gainful employment. 
Agnieszka KOZERSKA. Life satisfaction among people aged 60 and over, participating in restricted social networks in Poland: Related variables

OF EDU

PROBLEMS

IN THE $21^{\text {st }}$ CENTURY

Volume 67, 2015

Social exclusion among older people may be associated with difficulties faced by the elderly when they are unable to adapt to dynamic changes occurring in the modern world. The papers on the quality of ageing often reveal the social activity as one of dimensions of so-called successful ageing (Rowe \& Kahn, 1998). People with whom an individual maintains relationships influence their perception of the world around them and how they experience their age-related changes. Interactions with individuals who perceive their lives in an optimistic way may have an impact on the subjective quality of life. Members of social networks provide emotional and instrumental support and help gather relevant information to solve problems. Some observations of other people in a similar situation can provide guidelines regarding successful activities. Social participation of seniors may be interesting not only from the standpoint of sociology, but also gerontology, adult education and social assistance (Wenger, 1991). From the perspective of adult education, the engagement of older people in developing relationships with other people is related to their learning and creating their identities. The ability to take charge of their lives, the ability to cope with different, sometimes difficult, situations in life as well as the related higher level of life satisfaction may be the result of such learning. According to Field (2000), most informal learning takes place in our everyday lives as a result of forming relationships with other people. Social interactions are key factors that influence creating and continuously evolving a set of beliefs, rules and behaviours, as well as developing the ability to understand the world (MacFarlane, 1995). Therefore, it can be assumed that individuals reporting higher levels of life satisfaction maintain relationships with a large number of people on a regular basis. This has been confirmed by research conducted by Litwin and Shiovitz-Ezra (2010), Fiori et al. (2006), Kozerska (2015). However, it might be interesting to consider the question of wellbeing among individuals having small social networks. What determines the perception of their life situation in a positive, optimistic way? Research conducted by Jeste et al. (2010) reveals that providing objective criteria for so-called successful ageing is not necessary to experience a high level of life satisfaction. Some discrepancies can be seen between the assessment of wellbeing among the elderly based on objective indicators and subjective assessment of seniors. The question of life satisfaction of individuals, who are reluctant to socialise, seems significant because numerous people in Poland have small social networks made up of a few people. Research concerning the determinants of life satisfaction and wellbeing among the elderly may be of particular significance, especially in Poland. Older adults living in this country are characterised as having poorer mental wellbeing than residents from other European regions. Additionally, the age of the Polish population is a negative predictor of life satisfaction, which means that older people are less satisfied with life (Czapiński, 2014).

Creating broad structures of social contacts favours a feeling of happiness in old age, however, it has been observed that the elderly often withdraw from social life and in many cases it does not have an impact on a fall in life satisfaction. In gerontological literature there can be found attempts to interpret the phenomena of restricting the number of own social networks by the elderly as something positive, related to the development of one's personality.

According to the socioemotional selectivity theory (Carstensen, 2006; Scheibe \& Carstensen, 2010), aging is associated with some changes in subjective perception of future; time perspective decreases, which is related to the awareness of lifetime horizons. When time is perceived as limited, present-oriented goals are prioritised over long-term goals. This, in turn, results in an increased focus on emotion-related goals. The regulation of emotional states becomes more important than other types of goals. As a result, older individuals tend to restrict their social contacts to accentuate those that are emotionally gratifying. At the same time, relationships that are only of superficial depth or evoking negative emotions are shed. Carstensen's research $(1992,2006)$ showed that although older adults engage in interactions with others less frequently than young adults, they find them satisfying and supportive. On the basis of a meta-analysis conducted by Wrzus et al. (2013), it can be stated that the size of social 
networks increases up until young adulthood and then decreases steadily later in life. However,
the social network composed of family members is stable in size from adolescence to old age.

English and Carstensen (2014) claim that older individuals, in a deliberate way, construct social environments that are emotionally satisfying.

The theory of gerotranscendence developed by Tornstam (2005) might help provide an understanding of the phenomenon of having reduced social networks by the elderly. According to the theory, a process of development and change is a key factor in old age. At this stage, the development involves self-understanding, self-knowledge and obtaining transcendent wisdom. The development of gerotranscendence focuses on an increased feeling of affinity with past and future generations, a decrease in interest in superfluous social interactions. Some authors (Villar, 2012) use the term of generativity to outline the development of older adults and socalled 'successful ageing'. Generativity is one of the stages of human development identified by Erikson initially concerning middle adulthood (Erikson 1982), then also concerning grandgenerativity (Erikson, 1986). The concept refers to behaviours related to helping, transmitting knowledge to the next generation, providing support to others as grandparents, mentors, friends. Looking at this concept through the prism of educational sciences, it is important to recognise that generativity in older age is associated with the social and personal development (Villar, 2012). The social development leads to actions taken by older adults to benefit the next generation, whereas the personal development concerns benefits of individuals related to finding the meaning of life and developing their competences in different areas of life. Both the socioemotional selectivity theory, the theory of gerotranscendence and the concept of generativity reveal that having poor social networks may be associated with lifestyle choices as well as an expression of personal development.

However, in many cases, social isolation, which was discussed by Kuchcińska (2009), results from external circumstances. As Mausch \& Ryś (2007) note, elderly people tend to be treated like children. This is reflected in the tendency not to respect the opinions of older adults who are frequently ignored during social decision making. According to Kuchcińska (2009), pauperism of elderly people in Poland and factors partially dependent on the elderly themselves, for example, learned helplessness, functional illiteracy lead to social exclusion among older adults.

The elderly having small social networks, made up of a few individuals, predominate in Poland (Kozerska 2015). The present article is a continuation of the author's considerations on social networks. As a result of a cluster analysis, Kozerska (2015) differentiated the following three types of social networks to which Polish senior citizens belong. The paper, by Fiori et al. (2006), provided the inspiration to name the types.

Type 1: the family and friends network type is composed of $27.3 \%$ of all respondents aged $60+$. These are people who have regular social and personal contacts with family members

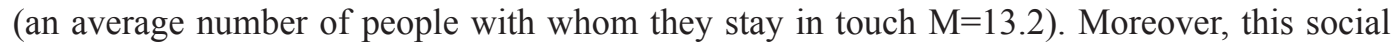
network also includes close friends $(\mathrm{M}=7.1)$ and friends with whom they maintain social contacts $(\mathrm{M}=7.6)$.

Type 2: the restricted network type includes $69.5 \%$ of all those polled. This is the most frequent social network type among Polish seniors who stay in regular social and personal contacts mainly with a small number of family members. They keep in touch regularly with 5 family members on average, 2 close friends $(M=2.6)$ and about 3 acquaintances $(M=2.7)$.

Type 3: the diverse network type is made up of people who are regularly engaged in social contacts with a wide group of people. The diverse group accounts for $3.2 \%$ of all respondents. People in this group have about 20 relatives, 17 close friends and 30 friends with 
Agnieszka KOZERSKA. Life satisfaction among people aged 60 and over, participating in restricted social networks in Poland: Related variables

OF EDUCA

IN THE $21^{\text {st }}$ CENTURY Volume 67,2015

32 whom they are in touch for social or personal purposes at least a few times a year. On average, they have the largest number of friends and family members with whom they are regularly in touch in comparison with the other two groups.

As a result of the analyses (Kozerska, 2015), it was stated that the 3 selected groups of seniors differ with regard to a majority of variables being indicators of the subjective quality of life. The diverse social network type presents the highest satisfaction level. Moreover, both the diverse type and family and friends type appear to be similar in terms of satisfaction derived from various fields of one's life. The family and friends group expresses a slightly lower level of satisfaction. The analyses showed that belonging to extended social networks is associated with the high subjective assessment of the quality of life. The restricted group, which is the largest one, the least educated and the oldest one at the same time, is characterised by the lowest level of satisfaction derived from all the fields of life being the main focus of the analysis. The obtained results are consistent with other authors' findings which show that the size of social networks shrinks as people age. Compared with the group belonging to extended social networks, restricted social networks are more frequent among older age groups.

The purpose of this article is to answer some questions regarding individuals functioning in restricted social networks. There has been defined a research problem: what are the determinants of a subjective assessment of one's own life carried out by Polish seniors functioning in restricted networks? In particular, there has been made an attempt to answer the question: does the age, level of education or gender diversify seniors as far as an assessment of one's own life is concerned? What spheres of life are taken into consideration when it comes to a general opinion of one's own life? Do seniors with a high subjective level of assessment of life differ from those with a low level of assessment in terms of what determines a successful and happy life? Are there any differences when it comes to ways of handling problematic situations?

\section{Research Methodology}

\section{General Characteristics}

In order to meet the set target, the data within the Diagnoza spoleczna project has been analysed (www.diagnoza.com). The objective of the project is a diagnosis of the conditions and quality of life in Poland. The research is regularly conducted (at intervals of several years) on a random sample of Poles and it is based on a panel form. The authors of the project belonging to the Social Monitoring Council are experts from various fields of science. Seven rounds of the research were carried out in 2000-2013. The Social Diagnosis (Diagnoza Spoteczna) is public and any interested party may download the database containing accumulated data from the research free of charge from the website.

\section{Sample selection}

For the purpose of the analysis, information regarding Polish seniors (individuals aged $60+$ ), gathered in 2013, was used. A randomly selected research sample included 9673 individuals - 5586 women and 4087 men. The research group was divided into three subgroups differing in terms of social contact networks. These three sub-groups are described by Kozerska (2015). This work presents more detailed information regarding one sub-group: 5623 individuals functioning in restricted social networks. 
Agnieszka KOZERSKA. Life satisfaction among people aged 60 and over, participating in restricted social networks in Poland: Related variables

\section{Procedure}

The analysed data comes from an interview conducted in the form of a questionnaire within the Social Diagnosis. There have been chosen items of the questionnaire which answered the research questions for the purpose of the analysis. These are statements to which the respondents had to take a stance by choosing one of the values on the scale, as well as statements the truth or falsity of which was to be assessed by the respondents. The respondents defined the level of satisfaction from selected spheres of life on the scales from 1 to 6 . Their own opinions, regarding the conditions of a happy life or factors determining whether the previous year was a successful one, were expressed by the assessment of the truth or falsity of given statements. Such information as the age, the number of years of formal education or gender, was also taken into consideration.

\section{Data Analysis}

Statistical analyses were performed using Statistica 10.0 programme. The MannWhitney $\mathrm{U}$ test and the two proportions test helped analyse the differences between variable distributions.

\section{Results of Research}

Subjective Assessment of Current Life of Seniors Functioning in Restricted Social Networks

Firstly, the variable Subjective general assessment of current life was analysed. Seniors who assessed their lives as great or successful made 34\% of the whole group (1917 people). $36 \%$ respondents (2032 people) assessed their lives as quite fine, and $21.3 \%$ as neither good nor bad (1198 people). 8.4\% respondents defined their lives as not very successful, unhappy or awful (470 people). $0.1 \%$ did not want to make any assessment (6 people). It can be stated that most seniors functioning in poor social networks define themselves as satisfied or quite satisfied with life, which is consistent with the socioemotional selectivity theory. However, the group functioning in little social networks is not homogenous in terms of a subjective assessment. Table 1 presents detailed comparisons regarding satisfaction from selected spheres of life of two extreme groups (34\% of the most satisfied and $8.4 \%$ of the least satisfied ones). It can be observed that group 1 (with a high general subjective assessment of life) has a higher level of satisfaction in every analysed sphere, particularly concerning relationships between close family members, for example, with children, a spouse and relationships with close friends. The result is in conformity with Carstensen's theory that people with a high level of life satisfaction tend to seek emotionally gratifying interactions with social partners. It results from table 1 that overall satisfaction is related to a higher level of satisfaction in every detailed sphere. 
Agnieszka KOZERSKA. Life satisfaction among people aged 60 and over, participating in restricted social networks in Poland: Related variables

PROBLEMS

OF EDUCATION

IN THE $21^{\text {st }}$ CENTURY

Volume 67, 2015

Table 1. Description of a level of satisfaction from selected fields of life of chosen senior groups.

\begin{tabular}{|c|c|c|c|c|c|}
\hline \multirow{2}{*}{$\begin{array}{l}\text { A field of life for which a level } \\
\text { of satisfaction was defined by } \\
\text { seniors } \\
\text { (higher values of the presented } \\
\text { scale refer to a lower level of satis- } \\
\text { faction; scale from } 1 \text { to } 6 \text { ) }\end{array}$} & \multicolumn{2}{|c|}{$\begin{array}{l}\text { Group } 1 . \\
\text { High subjective } \\
\text { general assess- } \\
\text { ment of life }\end{array}$} & \multicolumn{2}{|c|}{$\begin{array}{l}\text { Group } 2 . \\
\text { Low subjective } \\
\text { general assess- } \\
\text { ment of life }\end{array}$} & \multirow{2}{*}{$\begin{array}{l}\text { Significance of differ- } \\
\text { ences, result of Mann- } \\
\text { Whitney U test } \\
\text { U }\end{array}$} \\
\hline & M & SSD & M & SSD & \\
\hline $\begin{array}{l}\text { Relations with the closest family } \\
\text { members }\end{array}$ & 1.8 & 0.8 & 3.1 & 1.3 & $184675.5^{*}$ \\
\hline Financial situation of a family & 2.9 & 1.2 & 4.5 & 1.3 & $170357.0^{*}$ \\
\hline Relations with a group of friends & 2.5 & 0.9 & 3.1 & 1.2 & $251782.5^{*}$ \\
\hline One's own health condition & 3.4 & 1.3 & 4.5 & 1.3 & $239607.5^{*}$ \\
\hline One's own life achievements & 2.6 & 0.9 & 4.2 & 1.2 & $138458.5^{*}$ \\
\hline A situation in the home country & 4.3 & 1.2 & 4.9 & 1.0 & $308209.5^{*}$ \\
\hline The housing conditions & 2.2 & 0.9 & 3.4 & 1.5 & $220029.0^{*}$ \\
\hline Future perspectives & 3.4 & 1.3 & 4.7 & 1.2 & $191643.5^{*}$ \\
\hline Children & 1.7 & 0.7 & 2.6 & 1.3 & $167212.0^{*}$ \\
\hline Marriage & 1.8 & 0.7 & 3.6 & 1.5 & $40236.5^{*}$ \\
\hline
\end{tabular}

Source: own analysis based on: Social Monitoring Council (2013). Social diagnosis: an integrated database. www.diagnoza.com [access 13.02.2014].

${ }^{*} \mathrm{p}<.05$

Group 1 and group 2 are similar in terms of age. In both groups the arithmetic mean is 70 years, and a standard deviation is respectively: 8.0 and 8.1. Analysed groups differ significantly statistically in terms of number of years of formal education. The group with a higher level of life satisfaction is relatively better educated $(\mathrm{M}=10.5$ years, $\mathrm{SD}=3.3$ in comparison with $\mathrm{M}=9$ years, $\mathrm{SD}=3.2$ ). In group 1 every second person is a woman (55\%), while the group 2 is predominated by men $(67 \%)$.

\section{Selected Factors of Life Satisfaction of Seniors Functioning in Small Social Networks}

Further analysis is to compare individuals characterised by a high level of general life satisfaction and persons characterised by a very low level of overall life satisfaction to date in terms of opinions regarding the conditions of a successful and happy life. 
Table 2. Conditions of a successful and happy life in seniors' opinion.

\begin{tabular}{llllll}
\hline $\begin{array}{l}\text { Conditions of a suc- } \\
\text { cessful and happy life in } \\
\text { seniors' opinion }\end{array}$ & $\begin{array}{l}\text { Group 1. } \\
\text { High subjective general as- } \\
\text { sessment of life }\end{array}$ & $\begin{array}{l}\text { Group 2. } \\
\text { Low subjective general as- } \\
\text { sessment of life }\end{array}$ & $\begin{array}{l}\text { Significance of the differ- } \\
\text { ence - two proportions test. }\end{array}$ \\
\cline { 2 - 6 } & $\mathbf{N}$ & $\%$ & $\mathbf{N}$ & $\%$ & \\
\hline Health & 1384 & 72,3 & 378 & 80.6 & $p<0.05$ \\
\hline Children & 1110 & 58 & 178 & 38 & $p<0.05$ \\
\hline Happy marriage & 1197 & 62.5 & 132 & 28 & $p<0.05$ \\
\hline Providence, God & 325 & 17 & 120 & 25.6 & $p<0.05$ \\
\hline Money & 341 & 17.8 & 173 & 36.9 & $p<0.05$ \\
\hline Cheerfulness and optimism & 176 & 9.2 & 25 & 5.3 & $p<0.05$ \\
\hline Friends & 96 & 5 & 23 & 4.9 & n.s \\
\hline Education & 44 & 2.3 & 9 & 1.9 & n.s \\
\hline Freedom & 32 & 1.7 & 11 & 2.4 & n.s \\
\hline
\end{tabular}

Source: own analysis based on: Social Monitoring Council (2013). Social diagnosis: an integrated database. www.diagnoza.com [access 13.02.2014].

n.s. $=$ not significant

$\%$ refers to the number of respondents who answered affirmatively the given question.

Health is considered to be a condition of a successful life by group $1(72.3 \%)$ as well as relationships with close family members: with children (58\%) and a spouse (62.5\%). Group 2 considers health as a condition of a happy life $(80.6 \%)$, too. The other conditions of a happy life are listed more seldom in that group than in the previous one. Good relationships with others (e.g. with a spouse or children) are rarely considered as precious ones in that group. The difference is statistically significant $(\mathrm{p}<0.5)$. In group 2 money is more often considered to be a condition of a happy life (36.7\% in comparison with $17.8 \%$ in group 1). Group 1 values good relationships with others and, at the same time, it has good relationships with the closest ones. Almost all the people in group 1 (table 3.) agree with a statement that they feel loved and trusted in $(98.1 \%)$. In group 2 only every second person agrees to that $(53.3 \%)$. When asked if they feel lonely, even though they do not want that, almost all the seniors from group 1 denied such a statement (90.1\%, $\mathrm{N}=1693)$, while $65 \%$ (302 individuals) in group 2 answered affirmatively.

As it results from table 3 , group 2 shows more confidence in other people, by whom it feels loved and confided in. In difficult situations people with a high level of life satisfaction turn to others for help, but they also act themselves. Group 2 differs from group 1 in these terms. These are people who do not feel confided in by others and they also hardly ever turn to others for help. In difficult situations they are more often passive or they more frequently seek for consolation in a prayer than it happens in group 1 . 
Agnieszka KOZERSKA. Life satisfaction among people aged 60 and over, participating in restricted social networks in Poland: Related variables

OF EDUCATI

IN THE $21^{\text {st }}$ CENTURY Volume 67,2015

Table 3. Statements with which the respondents agree.

\begin{tabular}{|c|c|c|c|c|c|}
\hline \multirow[t]{2}{*}{ A type of a statement } & \multicolumn{2}{|c|}{$\begin{array}{l}\text { Group } 1 . \\
\text { High subjective general } \\
\text { assessment of life }\end{array}$} & \multicolumn{2}{|c|}{$\begin{array}{l}\text { Group } 2 . \\
\text { Low subjective general } \\
\text { assessment of life }\end{array}$} & \multirow[t]{2}{*}{$\begin{array}{l}\text { Significance of the } \\
\text { difference - two } \\
\text { proportions test }\end{array}$} \\
\hline & $\mathrm{N}$ & $\%$ & $\mathrm{~N}$ & $\%$ & \\
\hline $\begin{array}{l}\text { In difficult situations I turn to others } \\
\text { for help }\end{array}$ & 771 & 40.5 & 135 & 29.0 & $p<0.05$ \\
\hline $\begin{array}{l}\text { In difficult situations I motivate myself } \\
\text { and take actions }\end{array}$ & 919 & 48.3 & 117 & 25.1 & $p<0.05$ \\
\hline $\begin{array}{l}\text { In difficult situations I pray to God } \\
\text { for help }\end{array}$ & 633 & 33.2 & 197 & 42.3 & $p<0.05$ \\
\hline $\begin{array}{l}\text { In life 'the feeling of sense, achieving } \\
\text { important targets despite difficulties } \\
\text { and sacrifice' is more important than } \\
\text { 'pleasure, wealth, or lack of stress' }\end{array}$ & 1328 & 83.4 & 265 & 56.4 & $p<0.05$ \\
\hline I feel loved and confided in & 1868 & 98.1 & 248 & 53.3 & $p<0.05$ \\
\hline $\begin{array}{l}\text { I feel lonely even though I do not } \\
\text { want that }\end{array}$ & 187 & 9.9 & 302 & 65.2 & $p<0.05$ \\
\hline
\end{tabular}

Source: own analysis based on: Social Monitoring Council (2013). Social diagnosis: an integrated database. www.diagnoza.com [access 13.02.2014].

$\%$ refers to the number of respondents who answered affirmatively the given question.

\section{Discussion}

Most seniors functioning in restricted social networks define themselves as satisfied with life. General life satisfaction is related to a higher level of satisfaction in every analysed sphere. The result of analysis seems to be consistent with conclusions by Mather \& Carstensen (2003) that elderly people are characterised by selective attention, they tend to focus on positive information while negative information is not processed so intently. The results show that a poor social life of the elderly does not have to be linked with the feeling of loneliness. The group of individuals with a high level of general satisfaction is more satisfied with a relationship with the family (especially with children) than the group with a low level of life satisfaction. These are persons who feel loved and confided in. Such results confirm observations made by Halicka (2004) who carried out research on life satisfaction of the elderly in Poland. The author observed a regularity that there is a great similarity between the assessment of life satisfaction and the assessment of relationships with children. Bad relationships with children influence the low assessment of a current life situation. Such a correlation between life satisfaction and good relationships with the closest family can be explained on the basis of Carstensen's theory. It says that the awareness of life limitation in the elderly causes that emotional aims, focused on looking after the quality of relations with the closest family members, acquire particular significance. As regards Poland, it is important to note that the country is characterised by relatively strong family ties. According to the CBOS (Public Opinion Research Centre) survey from 2013 (Boguszewski, 2013) conducted on randomly selected sample of 1005 adult inhabitants of Poland, two-thirds of grandfathers (67\%) meet their grandchildren at least once every seven days, whereas $64 \%$ of parents also often meet their adult children living on their own. The analyses carried out herein present that individuals with a high level of satisfaction think that their happiness depends on good relationships with others. They are characterised by involvement regarding a focus on a significant goal for an individual. Such a sense of meaning, 
accomplishing goals despite obstacles and sacrifices are more important than pleasure, wealth and the absence of stress. Such involvement might be considered likely to relate to the goals

PROBLEMS

OF EDUCATION

IN THE $21^{\text {st }}$ CENTURY

Volume 67,2015 resulting from the value of generativity, because individuals with a high level of life satisfaction have close relationships with others belonging to their social networks. There are less people with a very low level of life satisfaction (less than $10 \%$ ). The data regarding the subgroup provide a picture of individuals experiencing loneliness who do not count (cannot count) on others to help them in especially difficult circumstances, claiming that maintaining close relationships with family and friends does not have a unique value. They state that health is a prerequisite for a successful and happy life, but at the same time, they tend to be dissatisfied with their health condition. Health problems may prevent and hinder them from maintaining satisfying relationships with other people. It may be assumed that they constitute a group of people for whom poor social networks are not their own lifestyle choices or personal development, but a necessity resulting from reasons beyond their control.

The observation that good relationships with family and friends are an important predictor of life satisfaction of the elderly has a special meaning if we consider seniors living in Poland. As it results from the research, Poles can be characterised by a low level of social trust (Growiec, 2009). It is typical not only for Poland but also for the other post-communist countries. As much as $70 \%$ of Polish seniors function in small social networks consisting mainly of family members. Only a small proportion of the elderly become involved in senior organizations (Kozerska, 2015). It is highly probable that a low level of social trust might be one of the reasons of little interest in activity in organisations of the elderly. In this case, specificity of Polish conditions should be taken into consideration while planning actions aiming at education development and improvement seniors' quality of life. Educational offers addressed at the elderly by TAUs or other senior organisations promoting knowledge are important but not enough. Seniors living in the country encounter difficulties in the access to them. Only $11 \%$ of Polish TAUs act in the country (the report Zoom na UTW 2012). Persons educated higher than average, those who are well off, with a higher social capital, and those from big cities participate in TAUs classes. The research within the report Zoom na UTW (2012) shows that TAU is perceived as an elite institution, and it causes that such an offer has no chance to reach all the seniors. This conclusion can be confirmed by an analysis (Kozerska, 2015) that poorly educated persons with low incomes often function in small social networks, consisting of a few people. In this situation, interactions with the closest ones - friends or family members, are the main factors influencing the quality of life. In terms of Polish conditions where most of seniors function in small social networks, informal learning in the family plays an important role. In gerontology little attention is paid to such a type of learning. The results of research presented in this article show that good relationships with the closest ones enhance resilience of the elderly, they are related to their life satisfaction, and in a way, they have some educational character. It is an informal education, resulting from life activities and challenges created by different life situations which an individual has to meet. This kind of education leads to a development of 'competences needed in overcoming problems of daily life, providing chances of survival, personal development and development of quality of social life, and cooperation (...)' (Solarczyk, 2000, p.106). Because of that it is worth taking actions promoting more involvement of grandfathers and grandmothers, as well as actions addressed to children and grandchildren of the elderly, encouraging them to nurture intergenerational bonds. As results of research on grandparents' participation in bringing up grandchildren show, seniors are not the only ones who benefit. The involvement of grandparents in bringing up grandchildren, the support given to their grandchildren is related to the quality of grandchildren's life (Kozerska, Napora \& Miszczak, 2015). In case of the elderly dealing with an illness or a disability, intrafamily support may be an important factor enhancing seniors' quality of life. Participation in informal, family networks may be an effective measure leading to gaining support. However, it 
Agnieszka KOZERSKA. Life satisfaction among people aged 60 and over, participating in restricted social networks in Poland: Related variables

\author{
PROBLEMS \\ OF EDUCATION \\ IN THE $21^{\text {st }}$ CENTURY \\ Volume 67, 2015 \\ 38 is needed to work on instruments which would support family caregivers. In the Polish realities \\ there are no mechanisms supporting caregivers of the elderly (Szukalski, 2008). In case when a \\ responsibility for a senior lies with one family member, the level of stress rises and the feeling \\ of burden is stronger in a caregiver, which in turn contributes to worsening of the quality of \\ support that is being given.
}

\title{
Conclusions
}

The analysis showed the importance of satisfaction from relationships with the closest family (a spouse, children, grandchildren) in comparison with the seniors' life satisfaction. Intergenerational relationships in the family constitute the main source of support in difficult situations, they are identified with the sense of security for many people. Taking into consideration a poorly developed institutional system of care services as well as services supporting independence, addressed to the elderly in Poland, the family is the main and often the only one source of emotional and instrumental help. The family's support is of major importance in case of the elderly, poorly educated ones, those with a low financial status. Individuals functioning in small social networks, consisting of a few people, dominate in this group.

A weak point of this work is a small number of variables under analysis and the data collected for the purpose of a project prepared in terms of a subject not related to the sphere of education. Deliberations in this article should be treated as an introduction to its author's further research on the intergenerational learning in the family.

\section{References}

Boguszewski, R. (2013). Więzi rodzinne. Raport CBOS. [Family ties. The Report of the Centre for Public Opinion Research]. Retrieved from http://www.cbos.pl/SPISKOM.POL/2013/K_107_13.PDF.

Carstensen, L. L. (1992). Motivation for social contact across the life span: a theory of socioemotional selectivity. In J. E. Jacobs (Ed.), Nebraska Symposium on motivation 1992: Developmental Perspectives on Motivation 1992 (pp. 209-254). Lincoln: University of Nebraska Press.

Carstensen, L. L. (2006). The influence of a sense of time on human development. Science, 312, 19131915.

Czapiński, J. (2014). Dobrostan psychiczny i społeczny Polaków w wieku 50 i więcej lat na tle wybranych społeczeństw europejskich. [Psychical and social well-being of Poles aged 50+ and over in comparison with selected European societies]. CenEA Research Note Series RN01pl/09. Retrieved from http://ibmed.ayz.pl/share/files/publikacje/cenea_rn01_09.pdf.

English, T., \& Carstensen, L. L. (2014). Selective narrowing of social networks across adulthood is associated with improved emotional experience in daily life. International Journal of Behavioral Development, 38 (2), 195-202.

Erikson, E. H. (1982). The Life Cycle Completed. New York: Norton.

Erikson, E. H., Erikson, J. M., \& Kivnick, H. Q. (1986). Vital involvement in old age. New York: Norton.

Field, J. (2000). Lifelong learning and the new educational order. London: Trentham Books.

Fiori, K. L., Antonucci, T. C., \& Cortina, K. S. (2006). Social network typologies and mental health among older adults. Journal of Gerontology, 61B (1), 25-32.

Growiec, K. (2009). Związek pomiędzy sieciami społecznymi a zaufaniem społecznym - mechanizm wzajemnego wzmacniania? [A relation between social networks and social trust - a mechanism of mutual reinforcement?]. Psychologia Społeczna, 1-2 (10), 55-66.

Halicka, M. (2004). Satysfakcja życiowa ludzi starych. [Life satisfaction of the elderly]. Białystok: Wydawnictwo Akademii Medycznej.

Kozerska, A. (2015). Social network types among Polish senior citizens and perception of the quality of their lives. Society, Integration, Education. Proceedings of the International Scientific Conference, 4, 67-79. Retrieved from http://dx.doi.org/10.17770/sie2015vol4.340. 
Agnieszka KOZERSKA. Life satisfaction among people aged 60 and over, participating in restricted social networks in Poland: Related variables

\author{
PROBLEMS \\ OF EDUCATION \\ IN THE $21^{\text {st }}$ CENTURY \\ Volume 67,2015
}

Kozerska, A., Napora, E., \& Miszczak, E. (2015). Zaangażowanie dziadków w ocenie wnuków z rodzin samotnych matek. [Grandparents' Engagement in the Opinion of Grandchildren from SingleMother Families]. Kultura i Edukacja, 1 (107), 231-246.

Kuchcińska, M. (2009). Edukacja przeciw marginalizacji seniorów. [Education against marginalisation of seniors]. Chowanna, 2 (3), 173-186.

Jeste, D. V., Depp, C. A., \& Vahia, I. V. (2010). Successful cognitiveand emotional aging. World Psychiatry, 9, 78-84.

Litwin, H., \& Shiovitz-Ezra, S. (2010). Social Network type and subiective well-being in a national sample of older Americans. The Gerontologist, 51 (3), 379-388.

MacFarlane, A. (1995). Future patterns of teaching and learning. The Changing University, 52-65.

Mather, M., \& Carstensen, L. L. (2003). Aging and attentional biases for emotional faces. Psychological Science, 14 (5), 409-415.

Mausch, K., \& Ryś, E. (2007). Starość jako piętno [Old age as the stigma]. In: B. Bugajska (Ed.), Życie w starości [Life in the old age] (pp. 175-184). Szczecin: ZAPOL.

Rowe, J. W., \& Kahn, R. L. (1998). Successful aging. New York: Pantheon Books.

Scheibe, S., \& Carstensen, L. L. (2010). Emotional aging: Recent findings and future trends. Journal of Gerontology: Psychological Sciences, 65B, 135-144.

Solarczyk, H. (2000). Edukacja ustawiczna $w$ Niemczech $w$ kontekście międzynarodowym. [Lifelong learning education in Germany in the international context]. Toruń: UMK Publishing House.

Szukalski, P. (2008). Rodzinne sieci wsparcia seniorów w starzejących się społeczeństwach-kilka refleksji [Family support networks of senior citizens in aging societies-some reflections]. Retrieved from http://repozytorium.uni.lodz.pl:8080/xmlui/bitstream/handle/11089/5331/Sieci\%20wsparcia\%20 -\%20Szukalski.pdf?sequence $=1$ \&isAllowed $=\mathrm{y}$

Tornstam, L. (2005). Gerotranscendence. A developted theory of positive aging. New York: Springer Publishing Company.

Villar, F. (2012). Successful ageing and development: The contribution of generativity in older age. Aging \& Society, 32, 1087-1105.

Wenger, G. C. (1991). A network typology. From theory to practice. Journal of Aging Studies, 5 (2), 147- 162 .

Wrzus, C., Hänel, M., Wagner, J., \& Neyer, F. J. (2013). Social network changes and life events across the life span: A meta-analysis. Psychological Bulletin, 139, 53-80.

Zoom na UTW. Raport z badania [Zoom on the UTA. The report from the study]. (2012). Retrieved from http://zoomnautw.pl/wp-content/uploads/2012/05/Zoom na UTW RAPORT calosciowy www.pdf.

Advised by Judita Stankutè, SMC “Scientia Educologica”, Lithuania

Received: September 12, 2015

Accepted: October 21, 2015

Agnieszka Kozerska

PhD, Professor, Institute of Pedagogy, Faculty of Pedagogy, Jan Długosz University in Częstochowa, Waszyngtona 4/8, 42-200 Częstochowa, Poland.

E-mail: a.kozerska@ajd.czest.pl 